DOI: $10.20472 / B M .2020 .8 .1 .008$

\title{
ECONOMIC POLICY RECOMMENDATIONS DURING THE CORONAVIRUS PANDEMIC IN THE CZECH REPUBLIC
}

\author{
MIROSLAV SEVCIK, ADELA ZUBIKOVA, JOSEF KLEMENT, JAN KOZAK, \\ MARTIN ZEMAN, PAVEL SMOLAK, TOMAS LEJSEK, LUBOR SIMUNEK, \\ KRISTYNA VESELA
}

\begin{abstract}
:
The authors of the paper formulated selected recommendations for economic policy in the Czech Republic, the aim of which was primarily to mitigate the economic effects of the COVID-19 pandemic and to prevent a long-term recession. The authors of the text believe that, in order to strengthen the robustness of the economy, it is essential to support not only the demand side of the economy but also the supply side through fiscal impulses from public budgets, which have been automatically used by governments across the European Union. Recommendations leading to the reduction of the tax burden, the elimination and reduction of selected tax rates or the cancelling of the next phase of electronic records of sales are presented. Fiscal measures are supplemented by recommendations for monetary policy - namely the reduction of the basic repo rate and warnings of breaches of the economic paradigm and moral hazard associated with the purchase of government bonds by the central bank. Furthermore, a proposal for the faster loosening of restrictions to allow the resumption of economic and educational activities is also presented. In support of industry, the authors of the text strongly warn against the acceptance of the "European Green Deal" which could permanently damage the competitiveness of the European economy and lead to a long-term reduction in the well-being of EU citizens. The authors also warn against the permanent implementation of regulatory elements into national legislation, which reduce the degree of individual freedom, increase the degree of redistribution and are thus in fundamental conflict with the principles of free market competition. Finally, the text draws attention to the Ratchet effect associated with all the discussed processes and to the degeneration of supranational institutions and their étatist attempts at destroying the market-conforming arrangement of economic and political conditions.
\end{abstract}

\section{Keywords:}

Fiscal policy, Monetary policy, Economic policy measures, Economic policy implications, COVID-19, Coronavirus, Czech Republic, Green policy

JEL Classification: E52, E62, H12

\section{Authors:}

MIROSLAV SEVCIK, Faculty of Economics, University of Economics, Prague, Czech Republic, Email: sevcik@vse.cz

ADELA ZUBIKOVA, Faculty of Economics, University of Economics, Prague, Czech Republic, Email: adela.zubikova@vse.cz

JOSEF KLEMENT, Faculty of Economics, University of Economics, Prague, Czech Republic, Email:

josef.klement@vse.cz 
JAN KOZAK, Faculty of Economics, University of Economics, Prague, Czech Republic, Email: jan.kozak@vse.cz

MARTIN ZEMAN, Faculty of Economics, University of Economics, Prague, Czech Republic, Email: martin.zeman@vse.cz

PAVEL SMOLAK, Faculty of Economics, University of Economics, Prague, Czech Republic, Email: pavel.smolak@vse.cz

TOMAS LEJSEK, Faculty of Economics, University of Economics, Prague, Czech Republic, Email: plevel123@gmail.com

LUBOR SIMUNEK, Faculty of Economics, University of Economics, Prague, Czech Republic, Email: siml02@vse.cz

KRISTYNA VESELA, Faculty of Economics, University of Economics, Prague, Czech Republic, Email: veselakristyna2001@gmail.com

\section{Citation:}

MIROSLAV SEVCIK, ADELA ZUBIKOVA, JOSEF KLEMENT, JAN KOZAK, MARTIN ZEMAN, PAVEL SMOLAK, TOMAS LEJSEK, LUBOR SIMUNEK, KRISTYNA VESELA (2020). Economic Policy Recommendations During the Coronavirus Pandemic in the Czech Republic. International Journal of Business and Management, Vol. VIII(1), pp. 155-175., 10.20472/BM.2020.8.1.008 


\section{Introduction}

We live in a globalized period of the modern digital age, which brings an immeasurable number of advantages to humanity, although its disadvantages are often forgotten. The global COVID-19 pandemic yet again exposed the weaknesses of a modern Western civilization founded on the principles of individual and economic freedom. Individual countries are facing one of the most significant attacks in modern human history on, not only their existing market-conforming arrangements of economic policy conditions, but also on their constitutive principles. Individual freedom is being limited by restrictive measures and digital technologies, all under the guise of protecting public health. While health protection is undoubtably essential, the current situation has seen fundamental and institutionally long-term attacks on the principles of free-market competition carried out away from public view. In this respect, this may be the greatest attack on capitalism and the associated market-conforming arrangement of economic policy that was born in the mid-18th century.

Yes, we have experienced world wars and efforts to build socialism in various parts of the world, be it efforts to build utopian socialism or to build communism. However, with a bit of exaggeration, it can be said that such a widespread attack on the foundations of capitalism, nota bene often sanctioned not only by the powers of state but by the citizens themselves, has not been seen in modern history. Even the Department of Economic and Social Policy team at the Faculty of Economics of the University of Economics in Prague ("DESP FE UE team") ${ }^{1}$ agreed with many anti-pandemic measures as logical outcomes of the evolving threat to health and the spread of the disease, while having reservations about the processes that occurred in relation to the resumption of economic activity.

The spreading coronavirus was an initial surprise for some and shock for others but within a few days or weeks we came to the realization that we live in a time of media panic and madness. The media literally managed to fool not only the politicians but most of the population. Not because of the strict, sometimes even exaggerated, phytosanitary measures that followed but because of what occurred after the initial restrictions on economic activity.

In a few years we may say that it was a shame to succumb to this historical and hysterical attack on the capitalist system and that all measures taken to restrict economic activity were excessive. Most citizens may also discover that the fear triggered primarily by a hysterical media was horribly paid for by a horrendous disruption of public finances. They may also discover that there has been a profound disruption of existing work habits, a loss of motivation and a distortion of the values recognized by society.

For those who wanted to build a classless, centrally administrated, state directed and planned communist society, this may be good news. For those of us who experienced these efforts in the second half of the 20th century, this remains unacceptable because we know that all these processes led to a deficient economy of scarcity, where limited resources could not be used efficiently in the long term.

\footnotetext{
1 The DESP FE UE team led by doc. Ing. Miroslav Sevcik, CSc. in composition: Ing. Adela Zubikova, Ing. Jan Kozak, Ing. Josef Klement, Ing. and Ing. Martin Zeman, Bc. Tomas Lejsek, Pavel Smolák, Lubor Simunek and Kristyna Vesela.
} 
Only in a society built on free competition and market-conforming relationships is a long-term increase of the standard of living possible. For us, this is a challenge to fight even harder to maintain individual freedom and to fight for its restoration where it has already been weakened. We are acutely aware that we must not allow ourselves to be enslaved through various pretexts or even be it creeping efforts.

This paper aims to capture, in chronological order, the economic policy proposals of the DESP FE UE team for supporting economic entities affected by the restrictive measures imposed by the decision-making (power) sphere and proposals for the liberation of economic activity.

An important aspect of this material is the time factor, because the DESP FE UE team continuously responded to the ever-evolving situation. Even in this paper, we must therefore reiterate the dates that individual measures were implemented and that our recommendations were formed, so that the dynamics of the anti-pandemic process could be understood in the future.

\section{DESP FE UE team recommendations related to the measures taken by executive powers in the Czech Republic}

The DESP FE UE team prepared our recommendations, some of which were prepared by the team members as early as March $17^{\text {th }}, 2020$ (Faculty of Economics of University of Economics in Prague, 2020b), less than a week after the first restrictive measures were set by executive powers in the Czech Republic. Such comprehensive proposals had not previously been published anywhere. The DESP FE UE team recommended the following measures for individual areas of the economy:

\section{$2.1 \quad$ Tax measures}

Abolishment of the personal income tax paid by taxpayers ("shared tax"), as follows:

- Abolish the obligation to file a tax return for 2019 for personal income, according to Section 7 of the Income Tax Act, No. 586/1992 Coll.

- In connection with this, cancel the payment of any advances for self-employed persons in 2020

The impact on the state budget could be estimated as the total planned revenue for 2020 , i.e. approximately 6.5 billion CZK minus the 0.89 billion CZK which was already collected in January and February. That is 5.61 billion CZK.

The impact on the other components of public budgets could be estimated as the total revenue for 2020, i.e. 8 billion CZK minus the 1.09 billion CZK which was already collected in January and February. That is 6.91 billion CZK.

We recommended similar measures for 2021. The expected impact on public budgets for 2021 was approximately 8 billion CZK. 
We further recommended:

- Lower the reduced VAT rate from $15 \%$ to $10 \%$ at least until the end of 2021 from the moment the amendment to the VAT Act No. 235/2004, Coll. takes effect. The expected impact for 2021 is $\mathbf{2 0} \mathbf{- 2 5}$ billion CZK.

- Abolish corporate income tax supplements for the year 2019 for companies with an annual turnover of up to 10 million CZK.

- Abolish corporate income tax advance for, at least, the tax period of 2020 for companies with an annual turnover of up to 10 mil. CZK.

- Reduce the VAT refund period from the current 30 days to 10 days with immediate effect, at least until the end of 2020. The state has no reason to withhold money from businesses who need it for their activities, especially at a time when their income has fallen sharply.

- Reinstate the VAT refund period of the current length of 30 days for 2021 and the following years.

- Increase the possibility of tax depreciation for the first group (depreciation for 3 years), for the second group (depreciation for 5 years), thus shortening them in both groups by one year and leaving more financial resources available for businesses.

\subsection{Social measures}

Enable a "carer's allowance" to the amount of $60 \%$ of salary for the entire period of the state of emergency for employees and for the self-employed (the state pays for both categories).

\subsection{Heath and social insurance}

Cancel self-employed social and health insurance payments for a period of 6 months for entities that get into secondary insolvency.

\section{$2.4 \quad$ Electronic Records of Sales (ERS)}

Cancel the introduction of the third and fourth waves of ERS in a shortened legislative procedure.

\subsection{Emission allowances}

The DESP FE UE team initially proposed abolishing emission allowance payments by the end of 2021 for previously obliged entities.

After deep analysis, the DESP FE UE team proposed abolishing emission allowance payment obligation until the public budgets in individual EU countries become balanced. This conclusion is different from the conclusion published in mid-March 2020 when the cancellation of emission allowances was recommended only until the end of 2021. Given the development of the situation and an assessment of the expected positive impact of the cancellation of emission allowances on the economic entities concerned, we proposed the situation stated above.

This would make it possible to stop or slow down any increase in energy prices. In certain circumstances, this measure may also lead to lowering prices for the final consumer.

\subsection{Measures for the automotive industry}

The DESP FE UE team proposed a repeal of the measures already taken by the European Union within the framework of promoting electromobility (European Commission, 2019a). These 
measures would undoubtedly create a serious threat to the economy of the Czech Republic due to the high share of the automotive industry on total production.

We recommended delaying the implementation of other measures of the "European Green Deal" (European Commission, 2019b), which borders on being a "climate religion to zealotry". In connection with this, it is worth considering revising the activities of commissions such as the "Coal Commission", etc.

\subsection{Emergency measure financing sources}

We proposed a one-off reduction of the operating costs of individual chapters of the state budget in 2020 by $10 \%$.

Other sources of financing would come from savings created by adjusting the state budget, which should reduce payments to all non-profit institutions except those that provide social services within the Czech Republic (non-profit costs amounted to 18 billion CZK in 2019) and from the issue of government bonds.

Given the exceptional nature of the situation, restarts of entire sectors of the economy must be ensured (tourism, transport, services, hospitality, etc.). A significant increase in the public budget deficit can therefore be expected, which will undoubtedly exceed $3 \%$ GDP. The Czech Republic can afford the above mentioned as it remains one of the least indebted countries within the European Union (Statista, 2020).

\section{Monetary policy measures}

As early as $19^{\text {th }}$ March 2020 , the DESP FE UE team prepared a charter, which was signed by a number of other academics and which focused on individual measures in monetary policy areas (Faculty of Economics of University of Economics in Prague, 2020b).

The global economy has fallen into the coronavirus trap. Politicians and economists are looking for ways to mitigate the effects of the current unprecedented processes. It is already clear to many that individual economies will be worse off in the coming months than they were during the financial crisis in 2008-2009. At that time, primarily the financial sector failed. Now, however, the whole real economy is affected, from industrial production, transport, services (especially tourism and hospitality) and foreign trade to agriculture. Significant shocks are also affecting stocks and bonds markets as well as other financial market sectors.

One does not need a higher education to realize that we are stand on the threshold of a deep and possibly long economic crisis. It is obvious that we have only a limited number of tools to eliminate the impacts and that, in addition, extremely fast decision-making is critical.

In accordance with the CNB's previously adopted recommendation, we proposed the following measures to mitigate negative effects on households, especially, but also on companies in the Czech Republic.

We called on all banking entities operating in the Czech Republic to voluntarily agree to defer (we emphasize "defer" not "pardon") the repayment of all loans and interest from $1^{\text {st }}$ April 2020 for those economic entities, i.e. households and companies, who so request and who have a valid and substantiated reason to do so, without any sanctions against them. We believe that banking entities can afford this measure because, at present, we consider the banking sector in the Czech Republic to be the most stable of all the countries of the European Union, perhaps including that 
of Switzerland. The vast majority of banks in the Czech Republic have no fundamental liquidity problems, unlike most banks in other European Union countries.

This measure would significantly improve the cash flow of not only households affected by declining incomes (especially those with mortgage repayments) but also companies affected by production interruptions or companies whose production expects to face a drop in demand. We would prefer that the availability of new loans does not decrease in the coming months due to this measure.

This is a moral appeal to banks and to the Czech Banking Association. This measure is urgent and cannot be enforced by legislation in a short period of time.

The measure could be primarily almost budget neutral and viewed as a bank's solidarity with its clients. We are aware that this is a non-systemic measure, but it is suitable for the extraordinary situation in which not only our economy has found itself.

Extraordinary times require extraordinary measures.

We further proposed:

- Not adopting the forthcoming amendment to the Act on the Czech National Bank (CNB), which excessively increases power of the CNB to implement restrictions and interventions in the financial sector and which will, among other things, make it more difficult to obtain mortgages, etc.

- A further reduction in interest rates by the end of March 2020 by $0.25-0.50$ basis points to 1.25 to $1.50 \%$ for the repo rate.

- The DESP FE UE team fundamentally disagreed with the ECB's procedure for setting basic interest rates to negative values.

The DESP FE UE team strongly warned against the measures currently used by the European Central Bank (ECB), which could lead to the financing of government debt through primary purchases of government bonds by the CNB. ${ }^{1}$

The demand from the third parties for the issue of government bonds so far exceeds their supply, so there is no reason for the "quantitative easing of money" by the CNB. So far, the data on recent government bond issues below shows that there are no economic reasons for these interventions by the CNB.

In addition, the DESP FE UE team warned that some CNB employees could fear government officials, that interest in government bond issues will decrease and demand immediate measures to be taken to enable the CNB to purchase government bonds under a special regime - see efforts to shorten the legislative process in the adoption of an amendment to the Act on the CNB, relating to open market transactions and credit operations.

The results of bond auctions, which already took place during the coronavirus crisis at the end of March and the beginning of April 2020, testify that fears of insufficient demand for bond issues are so far unfounded. On March $23^{\text {rd }} 2020$, the total demand for issued bonds was 61.0 billion

\footnotetext{
${ }^{1}$ On 4 May 2020, the Second Chamber of the German Constitutional Court ruled that the ECB's activities in connection with the PSPP program, under which the ECB purchases securities from various EU countries through the central banks of Member states, have been partially incompatible with the German constitution and if the ECB fails to implement corrective measures within three months, the German central bank would have to withdraw.
} 
CZK for the sale of 55 billion CZK (MFČR, 2020d). On March $26^{\text {th }} 2020$, the total demand was 74 billion CZK for the sale of 68.6 billion CZK (MFČR, 2020b). With the issue of April $1^{\text {st }}$ 2020, demand even reached 161.4 billion CZK for sales of 88.6 billion CZK, so demand almost doubled (MFČR, 2020a). A similar trend continued throughout the month of April and the first half of May 2020 (Kurzycz, 2020).

\section{Other DESP FE UE team proposals}

In early April 2020, the DESP FE UE team drew attention to the unprecedented processes that the Czech and global economies can expect in the coming months.

Due to the extraordinary nature of the situation, it is necessary to ensure a restart of whole sectors of the economy, already mentioned above, i.e. tourism, transport, services, hospitality, etc., and therefore we expect a significant increase in the public budget deficit, undoubtedly exceeding 3\% of GDP. At nominal GDP in 2019 (5652.553 billion CZK), this would amount to 169.58 billion CZK. For this year, we will see a decrease in nominal GDP in the order of hundreds of billions of CZK, so it a higher state budget deficit must be expected, which may reach more than $5 \%$ of nominal GDP (iDnes, 2020).

The Czech Republic can afford the above mentioned because the Czech Republic is still one of the least indebted countries in the European Union (Statista, 2020).

The DESP FE UE team strongly emphasizes that potential recipients of aid from public funds cannot be discriminated against just because their registered office or business activity is located in specific territorial units (for example in Prague), whose support is not recommended or is even banned by the eurocracy of Brussels (Echo24, 2020b).

The DESP FE UE team fundamentally disagrees that the "coronavirus situation" be misused for the inadequate easing of budgetary discipline up until 2027. It considers this process to be irresponsible with potentially harmful consequences for the young generation in particular. If the course of the economic cycle requires the easing of budgetary discipline, this measure should end immediately after the economy (measured by positive real GDP growth) experiences growth for 2 consecutive periods.

The DESP FE UE team emphasized that the use of Keynesian instruments, in the form of stimulating the demand side in the economy (universal financial payments, various subsidies, etc.), is significantly more financially demanding than going the way of stimulating the supply side of the economy. This means, among other things, reducing the tax burden, targeted stimulation to the truly in need and to entities (households and companies), who are directly affected by the anti-coronavirus measures of the state.

The DESP FE UE team recommended abolishment of the real estate acquisition tax without any further conditions.

The DESP FE UE team recommended considering whether it was time to reduce excise duty on diesel and petrol to a level that would not exceed the minimum rate set by the EU.

The DESP FE UE team commented continuously on the ongoing economic and political measures announced under a state of emergency, including $26^{\text {th }}$ March 2020 and $27^{\text {th }}$ March, 2020. The team pointed out that government measures lacked the calculation of the effects of the decline in revenues from individual taxes on the state budget, respectively on national revenues from individual taxes. The team reiterated its call for cancelling the introduction of the third and fourth stages of ERS and recommended cancelling social insurance payments by the self- 
employed for a period of 6 months, while allowing this time to count as an economically active period. The self-employed will not be helped by the mere postponement of these payments, for those affected the availability of funds must be ensured for at least 6 months.

The DESP FE UE team pointed out that these methods of assistance made available from public budgets may allow economic entities to receive funds because they apply for financial assistance even though they are not affected by the coronavirus pandemic.

The DESP FE UE team accepted the introduction of "kurzarbeit" (short-time working) and noted that the estimate of the Ministry of Labour and Social Affairs of the Czech Republic for the assistance provided during two weeks in March accounts for approximately 11 billion CZK (iROZHLAS, 2020b). It follows that each month of assistance will burden the state budget by approximately 22 billion CZK.

The DESP FE UE team assumed that the relevant state institutions will clearly determine the period that the antivirus program will be implemented for. The team expects that the implementation of this program will be confirmed as valid only for the period of the state of emergency.

\section{DESP FE UE team comments on other progressive economic policy measures of the Czech government}

- The government will pay a lump sum of 25,000 CZK to self-employed persons affected by the spread of coronavirus. Originally, several conditions were set but, after a wave of criticism, the Ministry of Finance agreed on a practically flat-rate payment for all selfemployed persons doing business before $13^{\text {th }}$ March 2020. (MFČR, 2020c)

The DESP FE UE team pointed out that this is a comprehensive measure, within which funds can be drawn by those self-employed whose activities are not directly affected by the coronavirus pandemic. From an economic point of view, these are the so-called "fare evaders". The DESP FE UE team recommends that this benefit should be paid only to the self-employed affected by the coronavirus situation. The amount of $25,000 \mathrm{CZK}$ should also be made available for newly active entrepreneurs, whose activities began in the previous year and were actively carried out until the government measures against the spread of coronavirus were implemented, and whose work activities were canceled or limited due to the state of emergency. The amount of 25,000 CZK should be paid only to those who prove that in 2019 they had income (not profits) of at least ten times that amount. It is inadmissible to pay out a universal amount to those who have an "active" trade license, but who have not performed the trade at all or only partially in the last year.

- Announcement of a moratorium on the repayment of loans and mortgages, which will be binding for all banks and non-banking companies, after approval by Parliament and becoming effective, for loans agreed before $26^{\text {th }}$ March 2020 (MFČR, 2020f)

As early as March $19^{\text {th }} 2020$, the DESP FE UE team recommended postponing the repayment of all principal and interest for 6 months for those economic entities (i.e. households and companies) that request it without any sanctions against them. As the DESP FE UE team mentioned earlier, the Czech banking sector is the most stable of all EU countries, possibly including that of Switzerland. The vast majority of banks in the Czech Republic have no major liquidity problems, unlike most EU banks, especially those within the euro area. 
The DESP FE UE team pointed out that this measure will significantly improve cash flow for households that are affected by reduced incomes (it would help with mortgage repayments in particular), as well as for companies that are affected by interruptions of production or companies whose production expects to face a decline in demand.

- Banning termination of lease due to the mere delay in the payment of rent, provided that the delay has arisen now, mainly due to the extraordinary measures that made it impossible or difficult for tenants to pay rent. (MMR, 2020)

The DESP FE UE team in no way recommended interfering with property rights and restricting property owners from managing their property. Housing allowance within the framework of existing legal norms could help socially needy tenants, or they could be helped by a different social benefit, albeit of a one-off nature. The DESP FE UE team pointed out that for rent and housing-related services (set by the normative housing costs), should these costs exceed $30 \%$ (in Prague 35\%) of the income of all household members, this household may apply for an existing option in the field of social benefits - housing allowance (see Act on State Social Support 117/1995 Coll. $\$ 24$ as amended by the Act of 2016).

- The possibility of postponing the maturity of repayments of loans provided by the State Housing Development Fund until $30^{\text {th }}$ November 2020. (MMR, 2020)

- Firms that are renting and have had to close their operations due to government measures will be able to request a postponement of the rent until $30^{\text {th }}$ June 2020 . They will be able to do so from $12^{\text {th }}$ March 2020. They will then have two years to pay the installments, until $31^{\text {st }}$ March 2022. If necessary, the deadlines will be extended by another three months. (MFČR, 2020e)

The DESP FE UE team recommended that the rent should be waived for the duration of the tenant's activity restrictions in cases where the landlord is a municipality or the state. Where the owner is a private person, it would be possible to request a refund of rent from the municipal or state budget up to the amount of locally usual rent, or rent according to a lease signed before $11^{\text {th }}$ March 2020 for all whose activities were limited by the state of emergency or by other restrictions imposed by state or municipal institutions.

- The government is considering that some key companies could be taken over by the state if they run into problems. This was confirmed to Czech Television by Prime Minister Andrej Babiš and the Minister of Industry and Trade Karel Havlíček. (Echo24, 2020a)

The DESP FE UE team did not agree with this solution. Any state participation in companies should be realized only by guarantees when issuing corporate bonds, with a maximum maturity of 36 months. This measure should make it possible to overcome liquidity problems or, temporary but difficult financial situations arising in connection with the measures taken by state institutions in the fight against coronavirus. This measure should be implemented only if companies request it themselves. In the case of additional loan financing, banks should take into account that these bonds are guaranteed by the state and should not include the amount of their issue in risky loans.

The DESP FE UE team recommended that any form of assistance from public funds should be conditional on the companies voluntarily not paying dividends and tantiums from economic results in 2019 and 2020. The rationale is, if companies can pay out dividends and royalties, they do not need to apply for financial assistance from public budgets. 


\section{Recommendations of the DESP FE UE team for the restoration of business and economic activities}

The DESP FE UE team stated in mid-April 2020 that, thanks to timely and drastic measures, the Czech Republic managed to sufficiently prolong the onset of the coronavirus pandemic. As a result, and despite the initial apparent difficulties, the health system did not collapse as it did at the beginning of the pandemic for example in China, Italy, Spain, France, Great Britain and the USA. At present, despite lack of knowledge about future developments regarding "immunization of the population", it is critically important to restore the economic life of society. We are aware that this cannot be a one-off event, but it will be a gradual process lasting up to several months in some areas.

The DESP FE UE team proposed systemic recommendations related to the measures published by the Czech government on $14^{\text {th }}$ April 2020 (iROZHLAS, 2020c). The Government of the Czech Republic originally recommended that all stores with an area of up to $200 \mathrm{~m}^{2}$ could be opened from Monday $27^{\text {th }}$ April 2020. Fourteen days later, from $11^{\text {th }}$ May 2020, it proposed opening all establishments with an area of up to $1,000 \mathrm{~m}^{2}$. Neither of these applied to large shopping centers, which were not to be opened until another month later, on $8^{\text {th }}$ June 2020.

The DESP FE UE team believed that systemic measures would consist of simultaneously opening all establishments up to an area of $1,000 \mathrm{~m}^{2}$ at a one time, provided that the existing hygiene rules would be met and that the persons would be at least $2 \mathrm{~m}$ apart.

In a simple calculation, this means that another person cannot be present within a length of at least 2 meters (which is the radius of the circle). This means $12.56 \mathrm{~m}^{2}$ of space per person $(3.14 \mathrm{x}$ $2^{2}=12.56$ ). Depending on the size of the store, all of them could be opened upon the condition that they will only allow the following number of customers to enter and that these customers will comply with the current hygiene standards:

Table 1 Recommended number of customers present in a retail space according to the size of the sales area

\begin{tabular}{|l|l|}
\hline Establishment size (in $\mathbf{~}^{\mathbf{2}}$ ) & Number of customers \\
\hline Up to 100 & 8 \\
\hline Up to 200 & 16 \\
\hline Up to 300 & 24 \\
\hline Up to 400 & 32 \\
\hline Up to 500 & 40 \\
\hline Up to 600 & 48 \\
\hline Up to 700 & 56 \\
\hline Up to 800 & 64 \\
\hline Up to 900 & 72 \\
\hline Up to 1000 & 80 \\
\hline
\end{tabular}

Source: own calculations 
Should it be found that stores with a sales area of more than $200 \mathrm{~m}^{2}$ have trouble complying with spacing between customers, the spacing could increase, for example, to 3 meters. It would be up to the store operators to decide whether to open or close a store under these conditions. This measure is systemic - in contrast to the unregulated entry, for example, to hobby markets.

The calculations in Table 1 are illustrative. The aim is not to mathematically maximize the number of circles that would theoretically meet the minimum spacing of two meters. Customers are not static figures, they move. People do not walk in circles around each other, but they change positions irregularly.

The point of calculations in Table 1 is to show that even larger stores can be opened at the same time as those with a smaller size provided that the maximum number of customers is respected.

We are aware that the distance between customers changes and that the required minimum distance cannot always be ensured, which is why this calculation was created. The mathematization of many phenomena in economics is problematic and the same applies to this case.

If all stores open systematically at once, customers will spread out over a larger area. This will reduce the concentration of customers in small stores (if only those up to an area of $200 \mathrm{~m}^{2}$ can open). The adoption of our proposals would also prevent the distortion of competition, which would arise by prioritizing the opening of stores up to $200 \mathrm{~m}^{2}$ over those whose area is larger.

At the same time, the DESP FE UE team pointed out that the government's proposed process for easing economic activity does not fully take into account the level of essentiality of various types of services with regard to the risk of disease transmission.

For example, opening driving schools 14 days earlier than hairdressing, pedicure, massage salons and regeneration services is a discriminatory approach because all of these services require similar sanitary precautions.

It is obvious that, hygienically and epidemiologically, driving schools, hairdressers and the other services are equally risky. We stress that practical teaching at the driving schools is carried out in a small, enclosed space. In addition, taken in the context of the entire national economy, the economic importance of, for example, driving schools is significantly lower than the economic importance of the release of all the other above-mentioned services. Assuming that there are no significant health and hygiene risks not yet known to the public, which could not be removed by an eventual tightening of the existing measures, we proposed making all of the above-mentioned services available at once, as early as $11^{\text {th }}$ May 2020.

The DESP FE UE team pointed out that it is unacceptable, especially in large agglomerations, to reduce public transport capacity at a time when economic activity is being renewed. This reduction would force individuals to travel in unnecessarily crowded public transport. This situation applies in particular to the Prague metro, which operates in holiday mode (Novinky, 2020b).

The DESP FE UE team expressed serious concerns that several measures aimed at tracing coronavirus carriers could be misused in the future through the unwarranted surveillance of individuals by government institutions, or by entities that could access sensitive data. The DESP FE UE team considered it unacceptable that BIS (Czech Security Information Service) or other state repressive bodies could restrict the possibility for residents to buy SIM cards freely without having to prove their identity (LUPA, 2020). 
The DESP FE UE team returned to its previous recommendation to abolish real estate transfer tax without any other conditions. This means that the possibility of applying interest deductions from the tax base should be retained if the property has been acquired through a mortgage loan.

7 Other recommendations and legislative change proposals aimed at lessening the damage caused to business entities

The DESP FE UE team concluded that data available as of $22^{\text {nd }}$ April 2020 has shown that minor steps taken to ease restrictive measures and a potential decrease in public discipline during the Easter holidays has not led to the deepening of the pandemic crisis in the Czech Republic. We recommended that the Government of the Czech Republic should set the ranges of basic indicators, e.g.:

- The relationship between the number of people tested and the number of people infected

- The relationship between the number of people infected and those who have a severe illness requiring hospitalization and artificial ventilation

Concrete steps to restore normal economic activity should be taken on the basis of the quantification and evaluation of these indicators. It is time to move on from ad hoc measures to systemic ones.

The DESP FE UE team considered the crisis mode adoption of a law that will enable a breach of budgetary responsibility rules in the medium term to be highly irresponsible (iROZHLAS, 2020a). The team was aware a significantly higher state (public) budget deficit, amounting to more than $4 \%$ of nominal GDP in 2020, must be expected. We did not, however, consider it economically justifiable for the law to allow the violation of the rules of budgetary responsibility to a similar level in 2021. We considered the prolonging of this situation until 2027 to be unacceptable.

While the DESP FE UE team was aware that it was difficult to precisely quantify the effects of the coronavirus pandemic and the related government measures on GDP development, we were certain that it will fall sharply. Just how sharply will depend on the speed and extent of economic activity resumption.

The DESP FE UE team further pointed out that the current wording of $\S 3$ of Act 182/2006 Coll. (The Act on Bankruptcy and Ways of Resolving It, or the Insolvency Act) may lead to many companies facing the prospect bankruptcy as soon as August 2020 and the following months. The DESP FE UE team proposed that the Legislative Council of the Government, in cooperation with the relevant ministries, should prepare an amendment of primarily Section 3 of Act 182/2006 Coll., which would extend debt payment and bankruptcy deadlines for an interim period (e.g. until 31.12.2021).

Specifically, it is $\S 3$ paragraph 1 letter $\mathrm{d}$ ): monetary liabilities for a period longer than 30 days after the due date. We proposed extending this period to 60-90 days.

In connection to this change, we proposed amending paragraph 2 letter b) of the Insolvency Act as well.

In relation to the expected growth of bad outstanding debts due to secondary insolvency, the DESP FE UE team proposed that these overdue receivables should be included in the tax base in 
the form of provisions from $100 \%$ of bad outstanding debts (Chamber of Deputies Parliament of the Czech Republic, 1992).

The DESP FE UE team recommended that the VAT payment obligation should be moved to after the invoice has been paid, at least for a transitional period (until $31^{\text {st }}$ December 2021). VAT would be due within 15 days of payment of the invoice. This measure prevents VAT payment for unpaid invoices and can thus help all business entities who have found themselves in a difficult financial situation through no fault of their own.

The DESP FE UE team also recommended speeding up the decision regarding abolishment of the real estate acquisition tax that we published an opinion on almost a month ago. Due to the expectations of involved parties, activity in this market segment has already slowed down (Echo24, 2020c). Further uncertainty about the property acquisition tax is undesirable for all transaction participants transactions as unfulfilled expectations are worse than an actual decision about whether or not to abolish the tax. The DESP FE UE team stood behind the opinion it published on $8^{\text {th }}$ April 2020 that the real estate acquisition tax should be abolished without any further conditions.

The DESP FE UE team reiterated that the Czech Republic should withdraw from the so called "European Green Deal" as soon as possible (European Commission, 2019b). This extremely costly and inefficient program cannot be implemented without serious negative socioeconomic consequences for most of the Czech population. This fact has already been pointed out by the DESP FE UE team in its previous proposals.

The DESP FE UE team recommended accelerating the process of economic activity resumption due to the relatively favorable development of the pandemic situation so far, dependent on the continuing future positive development of the pandemic indicators mentioned in above.

On $15^{\text {th }}$ April 2020, we suggested accelerating the restart of economic activities planned for $11^{\text {th }}$ May 2020 to $27^{\text {th }}$ April 2020.

Service provision activities that were to be renewed on $25^{\text {th }}$ May 2020 (e.g. barbershops, hairdressers, pedicures, masseurs, regeneration) should be moved to $27^{\text {th }}$ April 2020.

We proposed opening restaurants, bars, wine shops, summer gardens, taxi services as well as the indoor and outdoor areas of zoos to $11^{\text {th }}$ May 2020, provided that the established sanitary conditions are met.

We also proposed allowing sports events and other events for up to 100 people outdoors from $18^{\text {th }}$ May 2020 and allowing the examination period to begin at universities from $18^{\text {th }}$ May 2020, again under the conditions of sanitary rules being adhered to. The opening of theaters and cinemas, events in closed areas for up to 100 people as well as the opening of hotels, hostels, and shopping centers would then be allowed from $25^{\text {th }}$ May 2020.

\section{The DESP FE UE team on the further easing of socioeconomic life}

As of $28^{\text {th }}$ April 2020, the DESP FE UE team recommended that the Government of the Czech Republic should acquaint the public with the medical-pandemic indicators that must be met to allow the systemic release of other activities. An example is the $\mathbf{R}$ indicator and the value that must be met to relax the restrictions and return to a more normal rhythm of life. What 
values should the relationship between the number of tested and the number of infected people be? What other ratios must be met in order to end the restrictions of the right to movement, social interaction and other normal activities? Our further proposals concerned the business restoration processes and other related activities known at that point in time.

Due to the positive development of the set health and pandemic indicators, the DESP FE UE team recommended:

- Allow teaching activities at the 1 st stage of primary school from $11^{\text {th }}$ May 2020. As most medical experts claim that children are less susceptible to coronavirus infection and are better able to cope than other age groups, resuming compulsory schooling is imperative (Deník, 2020). At risk individuals would be excused from attending, as in the case of any other illness. This would reduce "carer's benefit" costs and the cost of other related social benefits. It would also allow those who otherwise must care for their children to resume full economic activity.

- The DESP FE UE team recommended starting regular teaching at the 2nd stage of primary school and at secondary schools from $18^{\text {th }}$ May 2020. Should compulsory school attendance not be restarted this school year, it would mean practically six months of absence (from March $11^{\text {th }} 2020$ to August $31^{\text {st }}$ 2020).

- Due to the fact that the provision restaurant and accommodation services is expected to be resumed from $25^{\text {th }}$ May 2020 at the latest, the DESP FE UE team recommended allowing school camps from $\mathbf{8}^{\text {th }}$ June 2020 (as most of them take place in accommodation facilities) for those schools that wish to do so.

- In the field of higher education, the DESP FE UE team recommended holding the examination period at universities within the originally planned dates so that exams could start from $18^{\text {th }}$ May 2020. Mass examinations and tests should be carried out in accordance with set sanitary regulations. Lecture hall capacity and other school premises could only be filled, for example, up 25\%-30\%. Only 100-120 people could therefore take written exams at once in a lecture hall with a capacity for $\mathbf{4 0 0}$ attendees, naturally while meeting required sanitary conditions. Capacities would be adjusted similarly other university premises. This capacity load would be similar to that already permitted in commercial premises.

The DESP FE UE team proposed that foreign travel for tourism could be allowed to countries that have taken at least approximately the same anti-pandemic measures and in which there is a comparable or lower level of risk associated with COVID-19 infection. The exact medical and pandemic parameters should be determined in advance by epidemiologists.

We recommended that outdoor sports events with the active participation of up to 100-150 people should be held from no later than June $8^{\text {th }} \mathbf{2 0 2 0}$. The maximum spectator capacity should be set at $\mathbf{5 0 0}$ spectators in outdoor stadiums with the necessary facilities (athletics, football, rugby). The specific number of spectators for individual sports venues should be determined so that the capacity is filled to a maximum of $30 \%$.

The DESP FE UE team also recommended extending the suspension of paid parking zones in cities until $25^{\text {th }}$ May 2020, when the last restrictions on business activities are to be lifted. The premature renewal of paid parking zones could lead to an undesirable increase in public transport passenger numbers. 


\section{$9 \quad$ Concluding notes}

On $5^{\text {th }}$ May 2020, the DESP FE UE team declared its awareness of the possibility of another coronavirus pandemic wave hitting the Czech Republic. The historical development of the Spanish flu pandemic has shown us that a second or even third wave may emerge. Despite this, in fact because of this, the DESP FE UE team drew attention to the need to relax restrictions so that fully fledged economic activity can be resumed as soon as possible. At the same time, it is vital to prepare both materially and mentally for a potential new wave of the coronavirus pandemic. If the restrictions are too harsh, the second wave will be delayed at the cost of extremely high economic losses and the paralyzed economy will not be able to effectively fight another wave. That is why it is loosening economic restrictions is critical, as is preparing for the implementation of anti-pandemic measures based on experience with the first wave. If it proves necessary, the renewal of restrictive measures will be easier to accept if in better economic shape than during a long-lasting economic depression.

The DESP FE UE team called attention to its proposal of $17^{\text {th }}$ March 2020, when it suggested a reduction in VAT from $15 \%$ to $10 \%$ for all items or at least for items that belong to essential goods. This reduction was recommended until at least $31^{\text {st }}$ December 2021 , but it could remain permanent for housing-related services and basic foodstuffs.

The DESP FE UE team reiterated its recommendations of $17^{\text {th }}$ March 2020 , $8^{\text {th }}$ April 2020 and $22^{\text {nd }}$ April 2020 to reduce the VAT refund period from the existing $\mathbf{3 0}$ days to $\mathbf{1 0}$ days, at least until the end of 2020. In the current situation, we preferred extending this period until the end of 2021.

For a transitional period (until $31^{\text {st }}$ December 2021), we recommended that the obligation for entrepreneurs to pay VAT be delayed until they have received payment of invoice. VAT would then be due within 15 days of payment. This measure would void VAT payment for unpaid invoices and could help all business entities who find themselves in a bad financial situation through no fault of their own.

The DESP FE UE team repeated its proposal from 17 ${ }^{\text {th }}$ March 2020 and $8^{\text {th }}$ April 2020 (Faculty of Economics of University of Economics in Prague, 2020a) related to the waiving of rent payments, which could help both landlords and tenants. We insisted that the rent be waived in cases where the landlord is a municipality or the state for the duration of the tenant's activity restrictions. The length of time could be extended by mutual agreement of the landlord (state or municipality) with the tenant. In cases with private landlords, the municipality or state would allow the tenant to request a refund of rent from the municipal or state budget. This refund could be either an amount reflecting locally usual rent, or the rental amount set in a lease agreement signed before $11^{\text {th }}$ March 2020.

The DESP FE UE team in no way recommended interfering with property rights and restricting property owners from managing their property. The state can support socially needy tenants within the existing framework of legal norms - with housing allowance or other oneoff social benefits. The team pointed out that if rent and housing related service costs exceed $30 \%$ (in Prague 35\%) of the income of all household members, this household can request a specific housing benefit - housing allowance. See the Act on State Social Support 117/1995 Coll. §24 as amended by the 2016 Act (Chamber of Deputies Parliament of the Czech Republic, 1995). 
We recommended that if the state views the capping of rent as necessary, then it should do so only for a clearly specified period or while emergency measures are in place. We did not agree with the indefinite freezing of rent.

The DESP FE UE team repeatedly proposed the definitive cancellation of the $3^{\text {rd }}$ and $4^{\text {th }}$ stage of the ERS system introduction. Developments so far have not confirmed the government's expectation that the introduction of ERS would dramatically increase the collection of VAT, personal income tax or corporate income tax (Euro, 2019). In recent years, the increase in these tax collections was mainly due to economic growth. In the case of VAT, the introduction of control reports also helped to increase collection. Should the 3rd and 4th waves of ERS be introduced from $1^{\text {st }}$ January 2021, it would bring both administrative and organizational costs not only for the payers, but also for state institutions. Most importantly, it is these groups of payers that are currently most affected by the coronavirus pandemic.

The DESP FE UE team did not recommend the introduction of so called scrapping schemes (Euro, 2020). Instead, it has long proposed a major overhaul of the emission limits set for the years 2021-2030, so that the limits are realistic in light of the current technological situation. This will avoid disproportionately high fines and sanctions, which are applied for noncompliance with the requirements set by the European Commission (according to Regulation 2019/631 of the European Parliament and of the Council) (European Commission, 2019a). It should be borne in mind that any penalties that car manufacturers must pay will be passed on to the final consumer in car prices. The unrealistically set parameters of the "EU green policy" could rapidly lead the European car industry into a situation where it cannot compete with non-European car manufacturers in the global market. The most affected countries will be the Czech Republic and the Slovak Republic.

With the introduction of a "Czech scrapping scheme", the Czech taxpayer would subsidize relatively rich German carmakers and through them, the German state. Only a small part of this support would fall on Czech subcontractors. To illustrate, Volkswagen's ownership structure includes one-fifth of the voting rights held by the federal state of Lower Saxony and $17 \%$ of the voting rights of held by Qatar Holding, founded by the richest state of Qatar. (Volkswagen, 2019)

The DESP FE UE team agreed with the opinions of a number of experts on the implementation of the so called "European Green Deal" and called on the political representation of the Czech Republic to withdraw from the implementation of this ill-conceived and highly ineffective plan. The final cost would be borne by every citizen of the Czech Republic.

The DESP FE UE team pointed out that almost all recommendations prepared by the Ministry of Education for the renewal of teaching at primary and secondary schools were unattainable under current conditions (Novinky, 2020a). The team believed that compulsory teaching at primary schools at both levels should be renewed and that parents who do not wish their children to attend classes would excuse them for health or other reasons.

The easing of measures during the examination period of higher education institutions should reflect the easing of measures for other mass events (cinemas, theaters). Students should sit exams only in number that correspond to the required distance of two meters apart. This means that in large auditoriums, more than the currently permitted 15 people could participate. Examination capacities should therefore be determined by the size of the room.

The DESP FE UE team was aware that the thawing of restrictions may be disrupted by a reemergence of a pandemic situation. Given the experience gained, the DESP FE UE team is 
inclined to believe that economic interventions should not be as massively widespread. Any necessary measures should be implemented in specific areas where the pandemic situation manifests itself. Decisions could thus be decentralized to the level of regions, municipalities, or areas.

10

Conclusion

It will take many years, perhaps decades, for the strong emotions associated with this historical episode of human development to subside. Many may at last understand that individual freedom and health are the most important values in human life. Freedom and health are irreplaceable. Our lives are touched by a live stream of media hysteria and, in some countries, the inability to deal with a crisis.

The executive branches of power need to gain an immediate understanding that complete isolation is not even a medium-term, let alone a long-term, solution to a pandemic. Yes, let's adhere to high sanitary standards, maybe wear face masks for a longer period of time, but let's not destroy the fine web of market relationships. We are not criticizing the measures that were rightly taken by our governing bodies at a relatively early stage to cushion the impact of the coronavirus attack, but we cannot agree with the relatively slow process economic activity resumption.

It is quite clear that a pandemic unfortunately brings with it a strengthening of the role of the state, which does not necessarily correspond with the "merit" of the state in solving the current situation. The supranational institution establishment (be it the EU, the WHO, the UN or others), which has completely failed in a period of pandemic madness, will no doubt seek to strengthen their position and their role in the future. We should step up our efforts to prevent these institutions from being strengthened.

Unfortunately, the Ratchet effect will be seen. Étatization will continue. The process of transition to cashless payments will speed up, spying will deepen under the pretext of clever quarantine and protection from God knows what else. There will be dozens of hostile processes aimed against a market-conforming environment and against individual freedom.

And how can this be countered? It barely can. But we remain optimistic. We believe that at least part of the population will retain a level of common sense that is not coronavirus debilitated, that they will not succumb to the lure of collectivism and will continue to stress the danger of losing individual freedom. We know from history that every restriction of individual freedom sooner or later led to a reduction in living standards, a reduction in personal well-being and to nationwide decline. For many, this is a period that will not be filled with an unbearable lightness of being. Hopefully, it will at least be a period of bearable hardship of being.

This text has been consulted and supported by the following persons:

prof. Ing. Vojtech Krebs, CSc.; prof. Ing. Karel Dyba, CSc.; prof. Ing. Kamil Janacek, CSc.; doc. PhDr. Jan Pavlik; doc. PhDr. Ing. Marek Louzek, Ph.D.; Ing. Jan

Skopecek; Ing. Lucia Bartusková, Ph.D.; Ing. Radek Heger, Ph.D.; Ing. Zdena Vostrovska, CSc.; Ing. Milan Bednar; Ing. Stepan Krecek 


\section{References}

DENÍK (2020) Roman Prymula: Riziko šírení koronaviru mezi dětmi je minimální. [Accessed 12 May 2020]. Available at: https://www.denik.cz/z_domova/koronavirus-cesko-deti-roman-prymula20200511.html.

ECHO24 (2020a) Babiš nevylučuje vstup státu do soukromých podniků. [Accessed 12 May 2020]. Available at: https://echo24.cz/a/SexGp/babis-nevylucuje-vstup-statu-do-soukromych-podniku.

ECHO24 (2020b) Pražské firmy mají smůlu. Na půjčku z programu COVID II zatím nedosáhnou. [Accessed 12 May 2020]. Available at: https://echo24.cz/a/SMWze/prazske-firmy-maji-smulu-napujcku-z-programu-covid-ii-zatim-nedosahnou.

ECHO24 (2020c) Schillerová brzdí realitní trh. Lidé kvůli jejímu slibu nekupují nemovitosti. [Accessed 12 May 2020]. Available at: https://echo24.cz/a/S4m4v/schillerova-brzdi-realitni-trhlide-kvuli-jejimu-slibu-nekupuji-nemovitosti.

EURO (2019) POMOHLA EET K VYŠŠÍMU VÝBĚRU DANÍ? ČÍSLA JSOU VYMYŠLENÁ, UPOZORŇUJE ANALÝZA. [Accessed 12 May 2020]. Available at:

https://www.euro.cz/politika/pomohla-eet-k-vyssimu-vyberu-dani-cisla-jsou-vymyslenaupozornuje-analyza-1438392.

EURO (2020) NESMRTELNÉ ŠROTOVNÉ. AUTOMOBILKY PROSAZUJÍ NÁVRAT OBLÍBENÉ DOTACE. [Accessed 12 May 2020]. Available at: https://www.euro.cz/byznys/nesmrtelnesrotovne-automobilky-prosazuji-navrat-oblibene-dotace.

EUROPEAN COMMISSION (2019a) CO2 emission performance standards for cars and vans (2020 onwards). [Accessed 12 May 2020]. Available at: https://ec.europa.eu/clima/policies/transport/vehicles/regulation_en.

EUROPEAN COMMISSION (2019b) European Green Deal. [Accessed 12 May 2020]. Available at: https://ec.europa.eu/info/strategy/priorities-2019-2024/european-green-deal_cs\#asov-osa.

IDNES (2020) Přebytek veřejných financí loni klesl na 0,3 procenta HDP, ř́kají statistiky. [Accessed 12 May 2020]. Available at: https://www.idnes.cz/ekonomika/domaci/prebytek-dluhcesko-rozpocet-hdp-verejne-finance.A200401_094317_ekonomika_rts.

IROZHLAS (2020a) Sněmovna přehlasovala Senát. Zákon umožňující vyšší strukturální schodky musí podepsat prezident. [Accessed 12 May 2020]. Available at: https://www.irozhlas.cz/zpravydomov/koronavirus-v-cesku-senat-snemovna-rozpocet_2004221246_pj.

IROZHLAS (2020b) Startuje program Antivirus. Stát bude přispívat na mzdy zaměstnanců, odhadem vyplatí 11 miliard. [Accessed 12 May 2020]. Available at:

https://www.irozhlas.cz/ekonomika/antivirus-covid-19-malacova-ministerstvo-prace-a-socialnichveci-koronavirus-v_2004061047_ban.

IROZHLAS (2020c) Vláda rozvolní opatření v pěti etapách. $V$ pondělí otevřou řemes/níci nebo farmářské trhy. [Accessed 12 May 2020]. Available at: https://www.irozhlas.cz/zpravydomov/koronavirus-covid-19-zasedani-vlady-otevreni-obchodu-finance-skoly_2004141743_aur. 
KURZYCZ (2020) Ministerstvo financí snižuje nabídku státních dluhopisů, zatímco zájem investorů přetrvává. [Accessed 12 May 2020]. Available at: https://www.kurzy.cz/zpravy/544328ministerstvo-financi-snizuje-nabidku-statnich-dluhopisu-zatimco-zajem-investoru-pretrvava/.

LUPA (2020) Věra Pohlová prodává online anonymní SIM karty z Česka, BIS se to nelíbí. [Accessed 12 May 2020]. Available at: https://www.lupa.cz/aktuality/vera-pohlova-prodava-onlineanonymni-sim-karty-z-ceska-bis-se-to-nelibi/.

MFČR (2020a) Dnešní aukcí MF pokrylo všechny letošní korunové splátky státního dluhu. [Accessed 12 May 2020]. Available at: https://www.mfcr.cz/cs/aktualne/tiskovezpravy/2020/dnesni-aukci-mf-pokrylo-vsechny-letosni-38073.

MFČR (2020b) MF opět zaznamenalo velký zájem o státní dluhopisy. Prodalo pokladniční poukázky za 68,6 miliardy. [Accessed 12 May 2020]. Available at:

https://www.mfcr.cz/cs/aktualne/tiskove-zpravy/2020/mf-opet-zaznamenalo-velky-zajem-o-statni37996.

MFČR (2020c) MF spouští přímou podporu pro zasažené OSVČ. [Accessed 12 May 2020]. Available at: https://www.mfcr.cz/cs/aktualne/tiskove-zpravy/2020/mf-spousti-primou-podporupro-zasazene-0-38055.

MFČR (2020d) MF uskutečnilo úspěšnou aukci státních dluhopisů za rekordně vysoké poptávky. [Accessed 12 May 2020]. Available at: https://www.mfcr.cz/cs/aktualne/tiskove-zpravy/2020/mfuskutecnilo-uspesnou-aukci-statnich-d-37985.

MFČR (2020e) Odklad splátek úvěrů a hypoték kvůli koronaviru. [Accessed 12 May 2020]. Available at: https://www.mfcr.cz/cs/o-ministerstvu/sluzby-verejnosti/komunikace-sverejnosti/casto-kladene-otazky/uverove-moratorium-38130.

MFČR (2020f) Vláda schválila moratorium na splátky úvěrů a hypoték. [Accessed 12 May 2020]. Available at: https://www.mfcr.cz/cs/aktualne/tiskove-zpravy/2020/vlada-schvalila-moratorium-nasplatky-uv-38077.

MMR (2020) “Nájemníkưm je třeba v nouzovém stavu rozhodně pomoci,” ríká ministryně Dostálová. [Accessed 12 May 2020]. Available at:

https://mmr.cz/cs/ostatni/web/novinky/najemnikum-je-treba-v-nouzovem-stavu-rozhodne-pom.

Faculty of Economics of University of Economics in Prague (2020a) Doporučení Katedry hospodářské a sociální politiky Národohospodářské fakulty VŠE v Praze k realizovaným hospodářsko-politickým opatřením v „období koronavirové pandemie“. [Accessed 12 May 2020]. Available at: https://nf.vse.cz/aktuality/doporuceni-narodohospodarske-fakulty-vse-v-praze-krealizovanym-hospodarsko-politickym-opatrenim-v-obdobi-koronavirove-pandemie/.

Faculty of Economics of University of Economics in Prague (2020b) VÝZVA AKADEMIKÜ Národohospodářské fakulty NF VŠE v Praze. [Accessed 12 May 2020]. Available at: https://nf.vse.cz/aktuality/vyzva-akademiku-narodohospodarske-fakulty-nf-vse-v-praze/.

NOVINKY (2020a) Dodržet vše je nereálné, myslí si o požadavcích ministerstva ředitelé škol. [Accessed 12 May 2020]. Available at: https://www.novinky.cz/veda-skoly/clanek/dodrzet-vse-jenerealne-komentuji-pozadavky-ministerstva-reditele-skol-40322828. 
NOVINKY (2020b) Spoje veřejné dopravy by se měly omezit, doporučila vláda. [Accessed 12 May 2020]. Available at: https://www.novinky.cz/koronavirus/clanek/spoje-verejne-dopravy-by-semely-omezit-doporucila-vlada-40318670.

CHAMBER OF DEPUTIES PARLIAMENT OF THE CZECH REPUBLIC (1992) Zákon České národní rady o rezervách pro zjištění základu daně z přímů. [Accessed 12 May 2020]. Available at: https://www.psp.cz/sqw/sbirka.sqw?cz=593\&r=1992.

CHAMBER OF DEPUTIES PARLIAMENT OF THE CZECH REPUBLIC (1995) Zákon č. 117/1995 Sb. [Accessed 12 May 2020]. Available at: https://www.psp.cz/sqw/sbirka.sqw?cz=117\&r=1995.

STATISTA (2020) National debt in EU countries in the 3rd quarter 2019 in relation to gross domestic product. [Accessed 12 May 2020]. Available at:

https://www.statista.com/statistics/269684/national-debt-in-eu-countries-in-relation-to-grossdomestic-product-gdp/.

VOLKSWAGEN (2019) Shareholder Structure. [Accessed 12 May 2020]. Available at: https://www.volkswagenag.com/en/InvestorRelations/shares/shareholder-structure.html\#. 